\title{
The Digitizing OF CoMPleX-SHAPEd REAL PART
}

\author{
MonKOVA, K. \& MonKA, P.
}

Abstract: The contribution deals with the digitizing of complex-shaped real part that exists in the plant without drawing documentation. There are described the needed steps of the surface digitizing and the advantages of created 3D model in the article. The new production technology of the part based on the 3D model can greatly affected the efficiency of the part manufacturing and so considerably decreases the economic cost for its manufacturing.

Key words: digitizing, 3D model, complex-shaped part
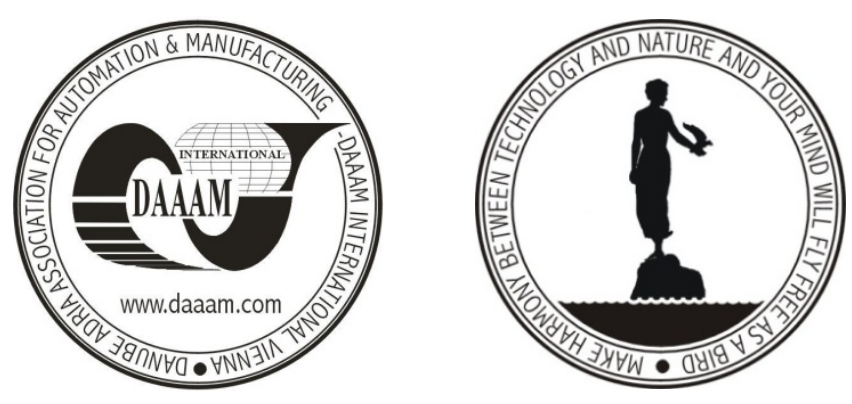

Authors' data: Dr. Doc. Eng. PhD. Monkova, K[atarina]; Dr. Doc. Eng. PhD. / prelector Monka, P[eter], Technical University in Kosice, Facuty of Manufacturing Technologies with seat in Presov, Department of Production Technologies, 31, 080 01, Presov, SK, monkova.katarina@apeiron.eu, direct@apeiron.eu

This Publication has to be referred as: Monkova, K[atarina] \& Monka, P[eter] (2008). The Digitizing of Complex-Shaped Real Part, Chapter 45 in DAAAM International Scientific Book 2008, pp. 535-542, B. Katalinic (Ed.), Published by DAAAM International, ISBN 978-3-901509-66-7, ISSN 1726-9687, Vienna, Austria DOI: $10.2507 /$ daaam.scibook.2008.45 